\title{
Urbanização e segregação sócio-espacial na cidade de São José dos Campos-SP: o caso Pinheirinho
}

\author{
Luiz Gustavo Forlin e Sandra Maria Fonseca da Costa*
}

\section{Resumo}

A cidade de São José dos Campos, localizada no estado de São Paulo, tem apresentado um intenso crescimento periférico, o qual tem se dado em duas direções: através da proliferação de loteamentos clandestinos e através do aumento no número de loteamentos voltados para a classe média/alta. Neste contexto, este crescimento urbano rápido, sob a égide do capital e de sua ramificação técnico-industrial, produz inúmeros movimentos de segregação sócio-espacial que margeia toda uma camada populacional de baixa renda e, comparativamente, também estabelecem as inúmeras zonas de alto padrão. Assim, a segregação urbana toma sentido quando há tendência à organização do espaço em zonas que apresentam "aglutinação de iguais" e, ao mesmo tempo, forte disparidade social. Estudar, sob a ótica da expansão capitalista dentro de um país subdesenvolvido como o Brasil, de suas ramificações associadas a um município de médio porte como São José dos Campos, dentro de sua via urbanizatória, tomando como exemplo mais premente a ocupação da área conhecida como "Pinheirinho", localizada na região sul da cidade, é a proposta final deste artigo.

Palavras-chave: Segregação sócio-espacial; Urbanização; Habitações; Direito à cidade.

\footnotetext{
Instituto de Pesquisa e Desenvolvimento - IP \& D / UNIVAP (gustavoforlin@hotmail.com) (sandra@univap.br).
}

Geosul, Florianópolis, v. 25, n. 49, p 123-158, jan./jun. 2010 
FORLIN, L.G. \& COSTA, S.M.F. da. Urbanização e segregação sócio-...

Urbanization and social-spatial segragation in the city of São José dos Campos-SP: Pinheirinho case study

\section{Abstract}

The city of São Jose do Campos, located in the state of São Paulo, has presented an intense peripheral growth, which has occurred in two ways: with the proliferation of illegal developments and also increasing the number of development oriented to the high/middle classes. In this context, fast urban growth, supported by the capital and its technician-industrial diffusion, produces uncountable movements of spatial-social segregation that borders all low income population and, comparatively, also establishes the high standard zones of occupation. Thus, the urban segregation occurs when a city has tendency to have spatial organization in zones of strong internal social homogeneity and high social inequality between them. Studying, under the optics of the capitalist expansion inside of an underdeveloped country as Brazil, its ramifications connected to a medium municipality as São José dos Campos, considering its urbanization, taking as a recent example the occupation of the area known as "Pinheirinho", located in the south region of the city, is the final proposal of this paper.

Key words: Social-spatial segregation; Urbanization; Housing; Rights to the city.

\section{Introdução}

O município de São José dos Campos, localizado na porção leste do Estado de São Paulo, é o maior, em termos de arrecadação de impostos, da região do Vale do Paraíba. O processo de industrialização começou a comandar o seu crescimento desde 1930, o qual produziu um crescimento urbano sem planejamento. Este processo acelerou-se depois da década de 1950, com a inauguração da rodovia Presidente Dutra, a instalação do CTA (Centro Técnico Aeroespacial), e do INPE (Instituto Nacional de 
FORLIN, L.G. \& COSTA, S.M.F. da. Urbanização e segregação sócio-...

Pesquisa Espacial), o que fez reafirmar a importante posição geográfica do município, situado entre as duas principais regiões metropolitanas do país (Rio e São Paulo). Após as década de 1070, o município ganhou notoriedade com a implantação de indústrias armamentistas, como a AVIBRÁS e a ENGESA, e a criação da EMBRAER e o desenvolvimento do setor aeronáutico. Proliferaram empresas de alta tecnologia, que prestam serviços às várias indústrias, o que faz com que o perfil de cidade "pólo tecnológico" se fortaleça.

Apesar de toda esta dinâmica econômica, se verifica que as riquezas geradas em seu território não impediram o surgimento de déficits na oferta de infra-estrutura e de serviços urbanos, o que comprometeu a qualidade de vida da população, principalmente, a de menor poder aquisitivo. A partir da década de1970, quando houve mudança no perfil do município, ocorreu uma reestruturação da área urbana, um intenso processo de urbanização e ampliação dos desníveis sociais (houve segregação sócio-habitacional como reflexo). Este crescimento econômico atraiu população de outros municípios e gerou um aumento das unidades habitacionais, para suprir a necessidade de moradia dos trabalhadores das indústrias e destes novos centros tecnológicos. Imóveis e localidades específicas foram se tornando alvos de domínio do capital e áreas centrais e suas proximidades foram valorizando-se, empurrando a população de baixa renda para áreas cada vez mais periféricas ao centro. Na ausência de uma política habitacional consistente, essa população desenvolveu mecanismos de contornar o mercado imobiliário e passou a ocupar os loteamentos e bairros clandestinos que hoje permeiam a cidade (somados ainda aos cortiços e favelas), sem que o olhar "público" se volta às necessidades destes.

Assim, na cidade de São José dos Campos, a exemplo do que ocorre em outras cidades brasileiras, emprestando os termos propostos por Maricato (2001), coexistem duas cidades: a "cidade legal", composta por loteamentos regularizados, atendida pelo poder público, servida por equipamentos urbanos e serviços, e a "cidade real", constituída por loteamentos irregulares e 
FORLIN, L.G. \& COSTA, S.M.F. da. Urbanização e segregação sócio-...

clandestinos, favelas entre outras formas de habitação alternativa. Para Souza (2003), um loteamento é considerado irregular quando não obedece ao que prevê a legislação que dispõe sobre o parcelamento do solo, isto é, quando não há nenhum projeto feito pelo loteador junto à Prefeitura e certas obras de infra-estrutura deixam de ser implantadas. "(...) Nossas cidades, cada vez mais, se dividem em duas. De um lado, a cidade dos que comandam e participam da sociedade, e de outro a cidade dos comandados, dos marginalizados, dos que estão de fora" (VILLAÇA apud FREITAS, 2004, p. 33).

O fato é que a reprodução destas duas formas distintas de cidade, a legal e a ilegal (ou real), propícia à segregação sócioespacial, estão interligadas e se elas são excludentes devido à dinâmica de suas condições e relações, completamente antagônicas, também se completam, pois são "fillhas" de um mesmo processo, de expansão capitalista numa cidade de médio porte, como São José dos Campos. Considerando esses aspectos, o presente artigo se propõe a apresentar um estudo da segregação sócio-espacial na cidade de São José dos Campos, localizada no estado de São Paulo, enfocando um caso de ocupação recente, que tem sido alvo de grandes discussões entre o poder público e a população excluída das condições de acesso à moradia: o Pinheirinho.

\section{Habitação e a cidade: as políticas habitacionais do município de São José dos Campos}

O atual estágio de exclusão social, e segregação espacial, em que nossas cidades se encontram, pode ser apontado como um dos reflexos do processo marcado pelo regime autoritário do desenvolvimentismo. A ocupação conhecida como "Pinheirinho", e os déficits habitacionais existentes na cidade de São José dos Campos são reflexos desta política. O processo de crescimento urbano e modernização vieram acompanhados de uma dívida social urbana, sendo a cidade de São José dos Campos um exemplo deste 
FORLIN, L.G. \& COSTA, S.M.F. da. Urbanização e segregação sócio-...

processo. Assim, torna-se relevante que se estabeleça um contexto da conjuntura associada ao setor habitacional como um problema de âmbito nacional, para compreender os programas habitacionais realizados tanto na esfera municipal quanto em outras instâncias.

Segundo Gouvêa (2003), no PDDI (Plano Diretor de Desenvolvimento Integrado) de São José dos Campos, elaborado em 1969, não havia nenhum artigo específico relacionado à política habitacional, aparecendo como um aspecto dentro das Diretrizes Urbanísticas. Este PDDI objetivou o adensamento de algumas áreas da cidade, sem que houvesse o aumento dos preços, impondo medidas como reduzir as unidades dos lotes em certos setores e construir casas em séries e em conjuntos habitacionais. Assim, procurou-se estimular a construção de loteamentos em áreas a serem adensadas e não aprovar novos loteamentos em setores periféricos, sendo que esta diretriz foi alcançada até o final da década de 1970. A partir de 1980, o perímetro urbano foi expandido e novamente o processo de dispersão da malha urbana retornado.

Na década de 1970, apesar de não haver estímulo a uma expansão horizontal, incentivando-se o adensamento de áreas com infra-estrutura disponível, os moldes desenvolvimentistas propuseram conjuntos habitacionais voltados somente à população que poderia ser atendida pelo Sistema Financeiro de Habitação, excluindo a população de baixa renda, que não tinha condições arcar com os custos de qualquer tipo de financiamento. Ou seja, não havia políticas referentes ao setor da Habitação Popular.

Somente ao longo da década de 1970, se iniciam as primeiras ações do poder público municipal referentes ao setor da Habitação Popular. Em 1976, por exemplo, é concluído o Conjunto Residencial Torrão de Ouro que fora destinado a atender parte da população removida de uma favela conhecida como Linha Velha. Esta remoção estava associada à construção de um novo sistema viário, o Anel Viário, o qual aumentaria a acessibilidade na cidade, sendo que a existência dessa favela significava um entrave a realização desta obra. 
FORLIN, L.G. \& COSTA, S.M.F. da. Urbanização e segregação sócio-...

A omissão do poder público em relação a esta população de baixa renda da cidade de São José dos Campos ocorreu diversas vezes: "em 1979 é criada a EMHA - Empresa Municipal de Habitação S.A. que se propunha a executar programas destinados aos financiamentos de lotes urbanizados e casas populares" (GOUVÊA, 2003, p.171), entretanto a população que estes programas iriam atender apresentava rendimentos de, aproximadamente, até 10 salários mínimos. Deste modo, as unidades habitacionais tornaram-se insuficientes e muitas vezes não atingiram a população mais carente, aquela que recebe até 3 salários mínimos.

Naquele mesmo ano é concedida à Prefeitura a posse da área conhecida como "Campos dos Alemães", a qual, devido à distância do centro e por não possuir nenhuma infra-estrutura instalada, foi utilizada para a instalação de conjuntos habitacionais. Nos anos 1980, por exemplo, foi implantado, no local, o conjunto habitacional Campo dos Alemães e o conjunto habitacional Elmano Ferreira Veloso, com financiamento da Prefeitura Municipal e destinado a atender a população mais carente da cidade, com rendimentos de 0 a 3 salários mínimos ${ }^{1}$. Este loteamento também foi estruturado para atender a população que residia na favela conhecida como "Vidoca", que se localizava às margens do rio de mesmo nome, no centro da cidade, o que despertou o interesse, preocupação e intenção do Poder Público local em estruturar conjuntos habitacionais populares.

A partir de 1981, a maioria dos programas habitacionais implantados no município recebeu financiamento para aquisição do lote e casa pronta, pela Caixa Econômica Federal, como os instalados nas unidades do Jardim Morumbi, Putim e outros bairros, os quais foram contemplados.

Nos anos 1980, há o agravamento da crise econômica do país, altos índices de desemprego e queda do padrão de moradia e

${ }^{1}$ Em janeiro 1988, o salário mínimo correspondia a CZ\$ 4.500,00 (aproximadamente US\$ 60,00 na época). 
FORLIN, L.G. \& COSTA, S.M.F. da. Urbanização e segregação sócio-...

de vida. O município de São José dos Campos sofre fortemente os efeitos da crise. A legislação de zoneamento vai sendo alterada, no sentido de dificultar o acesso à aquisição de lotes populares. Um exemplo é "a Lei $\mathrm{n}^{0} 3.110 / 86$, que restringiu o perímetro urbano e extinguiu a zona de expansão urbana" (GOUVÊA, 2003, p.174). Essa lei tornou cada vez mais difícil o acesso à moradia para a população de baixa renda, considerando que estas medidas tinham como fim elevar os valores do lote urbano em uma fase de recorrente crise econômica, impulsionando estas pessoas a adquirirem moradia em locais cada vez mais periféricos, e sem infra-estrutura.

Devido à situação de carência habitacional, vários projetos tiveram sua real intenção questionada, sendo acusados de terem caráter eleitoreiro. Um exemplo desse caráter eleitoreiro foi a divulgação, no final dos anos 1980, de programas habitacionais para as áreas remanescentes do Campo dos Alemães, sob a administração da URBAM-Urbanizadora Municipal, em que a construção das casas era programada pelo sistema de autoconstrução, custeada pelos moradores.

Em relação às críticas a estes programas habitacionais e mais especificamente aos modelos habitacionais da zona sul da cidade (onde iria configurar-se o Pinheirinho futuramente), Gouvêa (2003), ainda salienta:

"As críticas se estabeleciam, entre outros aspectos, pela escolha da área, que além de não dispor de nenhuma infraestrutura, tinha uma localização extremamente afastada e simbolizava a total exclusão sócio-espacial desta parcela da população, transformando um "programa habitacional" em um instrumento de segregação social onde estas pessoas se viam induzidas a ocupar uma área gigantesca, que durante muito tempo ficou marginalizada com preocupantes índices de violência (...), este loteamento ficou durante muito tempo com sérios problemas de infra-estrutura e equipamentos urbanos (...). Em 1990 esta área (...), teve uma parte destinada para a futura construção de conjuntos 
FORLIN, L.G. \& COSTA, S.M.F. da. Urbanização e segregação sócio-...

habitacionais, denominados D. Pedro I e D. Pedro II, os quais, associados ao Campo dos Alemães, acabaram formando uma verdadeira "cidade à parte pra a população de baixa renda, devido às grandes dimensões da área" (GOUVÊA, 2003, p.174-175).

No início da década de 1990, dado o crescente déficit habitacional existente no município de São José dos Campos, em especial na área urbana, a legislação de parcelamento, uso e ocupação do solo, Lei no $3721 / 90$, se volta à criação de loteamentos diferenciados, para as populações tipos " $\mathrm{C}$ " (de renda domiciliar de 6 a 16 salários mínimos) e " $D$ "(de renda domiciliar de 2 a 6 salários mínimos ${ }^{2}$ ). Na verdade, o que é estabelecido de forma efetiva é uma série de ações pontuais (e não contínuas), que até certo ponto atende à classe " $\mathrm{C}$ ", mas não as mais pobres, as do tipo "D" e "E" (com renda de até 2 salários mínimos), que foram excluídas destes empreendimentos habitacionais. Os empreendimentos habitacionais para a população destas faixas de renda, tanto nas mãos do poder público, quanto nas mãos do mercado, não tem a devida importância em função da quase inexistente possibilidade dessa parcela populacional em se capitalizar para adquirir um imóvel. Os empreendimentos do tipo "C" têm boa aceitação pelos empreendedores imobiliários pois não necessitam do cumprimento de algumas infra-estruturas, por serem caracterizados como loteamentos populares. $\mathrm{O}$ produto final deve sair por um valor conveniente ao loteador que visa o lucro de seu investimento, independente do seu caráter popular. Já o loteamento tipo "D" e "E", que deveriam atingir aqueles que realmente são carentes, não tem programas habitacionais aferidos.

Segundo Gouvêa (2003), ao longo das últimas décadas, as intervenções públicas realizadas em torno dos conjuntos habitacionais foram distribuídas entre as iniciativas da PMSJC, algumas participações da Caixa Econômica Federal e poucas

${ }^{2} \mathrm{O}$ salário mínimo, nesse período, era $\mathrm{NCz} \$ 1.283,95$, equivalente a US\$ 93,38. 
FORLIN, L.G. \& COSTA, S.M.F. da. Urbanização e segregação sócio-...

iniciativas do governo estadual por meio do CDHU (Companhia de Desenvolvimento Habitacional e Urbano). Entre 1990 e 1997, "de um total de 25 loteamentos aprovados, 15 foram do tipo ' $\mathrm{C}$ ', tidos como populares, porém sem atingir a população mais carente do município" (GOUVÊA, 2003, p.181). Nota-se, assim, que os programas para população de baixa renda de até 3 salários mínimos foram insuficientes para atender à demanda daquele momento. Ainda hoje, esta demanda encontra-se reprimida, visto que o rendimento mensal médio do joseense apresenta-se concentrado na faixa de rendimento abaixo de 3 salários. Segundo o Atlas das Condições de Vida de São José dos Campos ${ }^{3}$ (figura 1), no município de São José dos Campos 43\% dos domicílios apresentam rendimento mensal de até 3 salários mínimos (o percentual de domicílios nesta faixa de rendimentos chega a 70\% nos setores Campos dos Alemães, São Francisco Xavier, Favelas e Ocupações Irregulares). Levantamentos anteriores, como o censo demográfico de 1980 , demonstram que $37,53 \%$ dos habitantes do município estavam nesta condição e $40,61 \%$ estavam na condição de "sem rendimento". Em 1991, segundo o IBGE, 41,65\% não tinham nenhum rendimento e $32,59 \%$ possuíam renda entre 1 e 3 salários mínimos. Estes números se contrapõem à realidade econômica do município de São José dos Campos: um "tecnopólo" de representação não só regional, mas também nacional e internacional; segundo o SEADE (Sistema Estadual de Análise de Dados), em 2003, detinha o quarto melhor PIB per capita do Estado de São Paulo, a frente de cidades como Campinas e Osasco. Desta forma, se tem a percepção do quanto é discrepante a realidade sócio-econômica do município, onde, reiterando, quase metade dos domicílios apresentem rendimento de, no máximo, 3 salários mínimos.

Considerando estes aspectos, percebe-se a incapacidade do poder público em agir frente às necessidades sociais e, por

${ }^{3}$ Este Atlas foi elaborado em 2003, em pesquisa realizada por meio de uma parceria entre UNICAMP (Universidade de Campinas) e PMSJC. 
FORLIN, L.G. \& COSTA, S.M.F. da. Urbanização e segregação sócio-...

conseqüência, habitacionais do município. O município de São José dos Campos teve um grande crescimento demográfico e um intenso processo de urbanização, fatores que, somados aos sucessivos momentos de crise do país e, conseqüentemente, às sucessivas perdas do poder aquisitivo da população, têm contribuído para o déficit habitacional. São aspectos relevantes que certamente impulsionaram o aumento da demanda que se instaura nos recônditos periféricos de São José dos Campos, estimulando o mercado ilegal de terras (tornando-se esta uma atividade também lucrativa), o qual satisfaz a demanda daqueles que não tinham acesso ao mercado imobiliário formal, levando-os a construir suas casas de acordo com suas condições de renda.

O PDDI (Plano Diretor de Desenvolvimento Integrado), de 1995, salienta que as políticas de desenvolvimento urbano devem abranger tanto a cidade legal quanto a cidade real, esta permeada por inúmeras especificidades urbanas. A criação das Zonas Especiais de Interesse Social - ZEIS (instituídas nesse PDDI) teve $\mathrm{o}$ intuito de abranger áreas de favelas e loteamentos clandestinos, reconhecendo oficialmente a existência destes seguimentos. A "cidade ilegal" necessita ser integrada à "cidade legal" como forma de minimizar os problemas desta população, estabelecendo uma política habitacional pró-ativa, o que desestimularia o mercado de loteamentos clandestinos do município.

Atualizando-se a questão habitacional, vê-se o reflexo desta omissão, descaso ou mesmo pouca efetividade das políticas habitacionais públicas. Segundo a mesma pesquisa relatada anteriormente, realizada pela UNICAMP (Universidade de Campinas), o déficit habitacional da cidade é de 22 mil casas, mais do que o dobro de moradias que a PMSJC dizia ter até então, quando afirmava que o déficit habitacional era de 10 mil casas. A pesquisa inclui famílias que vivem em submoradias ou possuem cerca de $30 \%$ da renda mensal comprometida com pagamento de aluguel. $\mathrm{O}$ mesmo estudo revela que, aproximadamente, $56 \mathrm{mil}$ pessoas vivem em condições inadequadas de habitação, em 14 mil domicílios. O cálculo abranje submoradias, favelas e domicílios 
FORLIN, L.G. \& COSTA, S.M.F. da. Urbanização e segregação sócio-... alugados por famílias que têm rendimentos mensais inferiores a três salários mínimos e aplicam mais de 30\% do valor em locação de casas ou apartamentos.

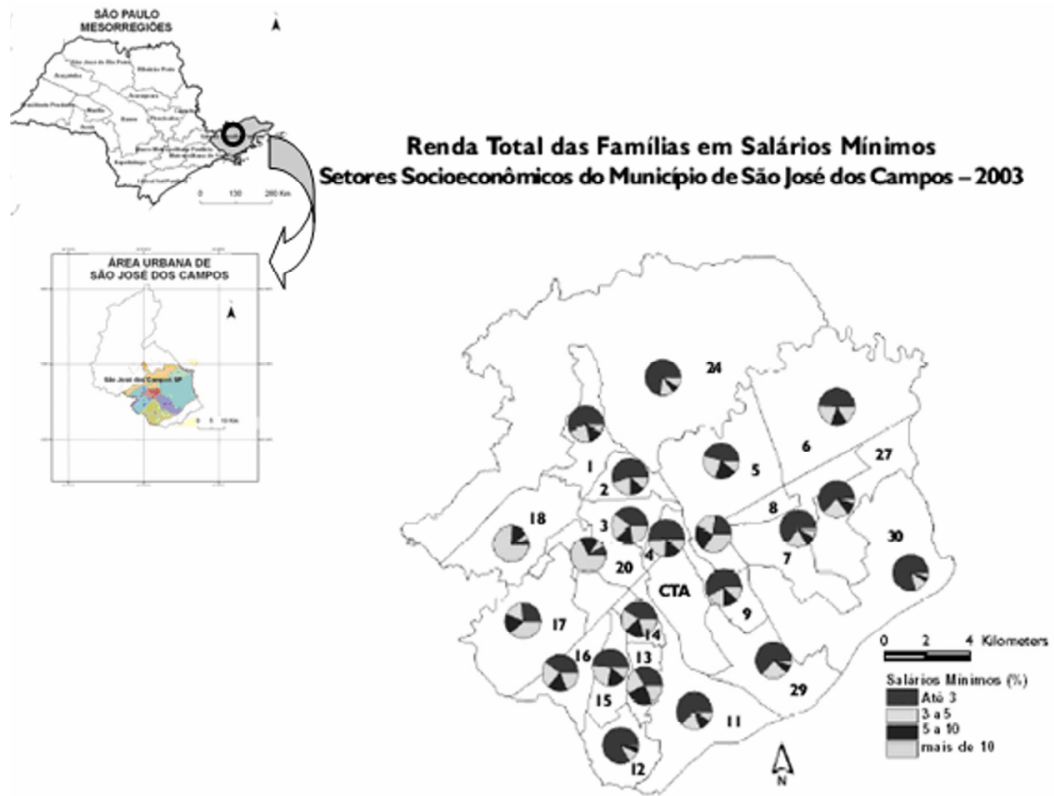

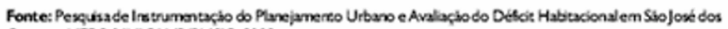
Campos. NEPO/UNICAMP/PMISYC, 2003.

\begin{tabular}{|c|c|c|c|}
\hline \multicolumn{4}{|c|}{ LECENDA } \\
\hline 1. Alto da Ponte & 7. Pararangata Canpos de S jook & 14-Jd Satelite & 21 - Sbo francisco Xavier \\
\hline 2-Santana & 3-Viata Verde & 15-Jd. Oriense Morumb & 24 - Frotas/Sertozino \\
\hline 3-Cenro & 9. H.daGraia & 16-Pargus hdustrial & 27 -Newo Horizonte \\
\hline 4-Jd. Paulsea & 11 - V.S. Benz/Torrio de Ouro & 17. H. das Indústrias & 29 - Putim \\
\hline 5-Vl holustrid & 12. Crmpo dos Alembes & 18. Urbanova/Aquiris & 30 - Capbo Grosso/Bom \\
\hline 6-Eugghio de Melo & 13 - Bosque dos Eucalptos & 20. U. Adyanna Explanoda & RetiralSerrote \\
\hline
\end{tabular}

FIGURA 1: Renda total das famílias em salários mínimos

Fonte: Pesquisa de Instrumentação do Planejamento Urbano e Avaliação do Déficit Habitacional em São José dos Campos. NEPO/UNICAMP/PMSJC (2003). 
FORLIN, L.G. \& COSTA, S.M.F. da. Urbanização e segregação sócio-...

O principal pilar das políticas municipais de habitação, a partir de 1997, foi o programa de "desfavelização" da administração do prefeito Emanuel Fernandes. O programa foi apresentado pela administração pública, inicialmente, sustentáculo das políticas habitacionais populares. Entretanto, foi bastante criticado pela sua aplicação, sendo considerado por estes como um programa de "limpeza urbana", o qual esconde os pobres do centro da cidade, já que as favelas seriam removidas destes centros para setores periféricos da cidade. A proposta principal incluiria apenas as famílias que moravam nas favelas da cidade, sem prever mecanismos eficazes para geração de renda e empregos para esses moradores nos locais para onde seriam transferidos. Sem dinheiro, muitos não conseguiam arcar nem com o pagamento da casa ou com a alimentação da família. Sem a garantia do emprego formal e sendo empurrada para a informalidade, a maioria dos moradores enfrentava dificuldades para arcar com os compromissos financeiros básicos, tais como as contas de água e luz, além da taxa mensal paga pelo financiamento da casa.

Há, ainda, inúmeros exemplos de ocupações e conflitos entre movimentos populares e Prefeitura que evidenciam a ausência de políticas habitacionais no município. Alguns exemplos:

a) Favela Santa Cruz I - Incluída no programa de desfavelização, há oito anos, 62 famílias foram removidas de suas casas para os apartamentos do Conjunto Henrique Dias. Atualmente, as famílias convivem com a precariedade de infra-estrutura e a não adaptação a este tipo de moradia, onde há vazamento de esgoto e água em praticamente todos os apartamentos. No local de suas antigas moradias foram construídos os prédios da Câmara Municipal, Fundhas, e hoje, a ampliação do estacionamento da Câmara. Hoje o conflito com a prefeitura é travado para que haja uma reforma no prédio urgentemente;

b) Vila Nova Tatetuba - Todas as famílias que residiam nessa favela foram expulsas e ou removidas do local, que era considerado zona de risco. Pouco tempo depois, O IPT 
FORLIN, L.G. \& COSTA, S.M.F. da. Urbanização e segregação sócio-...

(Instituto de Pesquisas Tecnológicas) forneceu um parecer afirmando que a área não possuía riscos de deslizamentos, como afirmado pela Prefeitura. Naquele espaço, deu-se a construção do Hipermercado Carrefour, bem como prédios residenciais voltados à classe média. Um grupo de exmoradores da favela Nova Tatetuba, conhecida como Morro do Regaço, se negaram a ir para as casas construídas no Jardim São José II e ocuparam a antiga estação de trem;

c) Projeto "Via Norte" e Habitação: Outros exemplos de conflitos recentes que tenham o mote "habitação" ocorrem em torno do principal projeto viário da gestão atual da Prefeitura, o qual foi aprovado em junho de 2006, com a liberação da licença ambiental fornecida pela Secretaria Estadual de Meio Ambiente, para a construção da "Via Norte", uma avenida que irá conectar a Zona Norte ao Centro. O projeto prevê, na primeira etapa, a remoção das moradias, cerca de 300 famílias que moram, desde 1931, na localidade conhecida como Nova Esperança. Para colocar em prática seu projeto, o poder público vem pressionando as famílias a aceitar uma proposta que só considera o valor material das casas e, mais recentemente, ofereceu $\mathrm{R} \$ 10 \mathrm{mil}$ por moradia, quantia considerada irrisória pelos moradores destes locais já que em pouquíssimos lugares esta quantia seria suficiente para construir outra casa.

Não cabe, nem é a pretensão deste artigo, detalhar todos os aspectos relacionados ao déficit habitacional do Município, dos recorrentes conflitos entre poder público e espaços segregados e das políticas habitacionais adotada pelo poder público (há ainda inúmeros outros exemplos envolvendo o problema habitacional, a questão fundiária e a cidade). Sem dúvida alguma, tratar de todas as ramificações que projetos como os de "desfavelização" ou o recentíssimo projeto viário da "Via Norte", dispenderiam outros níveis de análise. $\mathrm{O}$ objetivo foi apresentar, mesmo que não em sua amplitude, o quadro habitacional da cidade, como a questão evoca um senso conflituoso, entre diferentes esferas e interesses, quadro 
FORLIN, L.G. \& COSTA, S.M.F. da. Urbanização e segregação sócio-...

este que parece ter se acentuado nos últimos anos (vide projetos de "desfavelização" e "urbanização" de favelas, que são contraditórios em seu próprio nome), mas que tem sua gênese na própria história da cidade.

\section{A situação do Pinheirinho}

Um exemplo evidente de todos os processos arrolados até aqui, e enfoque premente deste artigo, refere-se à ocupação do Pinheirinho, como ficou conhecido o local e que será caracterizado no presente item.

\section{Ocupação do Pinheirinho: histórico e conflito}

A ocupação urbana do Pinheirinho, localizado na região Sul da cidade de São José dos Campos (figura 2) e próximo ao bairro popular conhecido como Campo dos Alemães, teve seu início em fevereiro de 2004, quando trabalhadores sem-teto ocuparam um terreno de 1,3 milhões de metros quadrados (57 alqueires), que estava abandonada há 30 anos, sem cumprir qualquer função social (cultivo ou moradia). O terreno é propriedade da empresa (massa falida) Selecta S/A, cujo proprietário é o megaespeculador Naji $\mathrm{Nahas}^{4}$, a qual, juntamente com a Prefeitura, vem travando a "queda de braço" com os ocupantes do Pinheirinho.

Atualmente, de acordo com a coordenação do movimento, moram no Pinheirinho mais de 7 mil pessoas, o correspondente a cerca de 1500 famílias. Cerca de 2.600 sem-tetos são crianças de 0 a 10 anos.

${ }^{4}$ Libanês naturalizado brasileiro que fez história no mercado acionário com jogadas de altíssimo risco, Naji Nahas já foi o maior investidor individual do Brasil, e, sozinho, controlava $6 \%$ dos papéis da Petrobrás e $10 \%$ da Vale do Rio Doce. À época, tais ações valiam US\$ 490 milhões. Foi o protagonista de um dos maiores escândalos do sistema financeiro nacional. Inúmeras acusações de corrupção pesam sobre o megainvestidor 
FORLIN, L.G. \& COSTA, S.M.F. da. Urbanização e segregação sócio-...

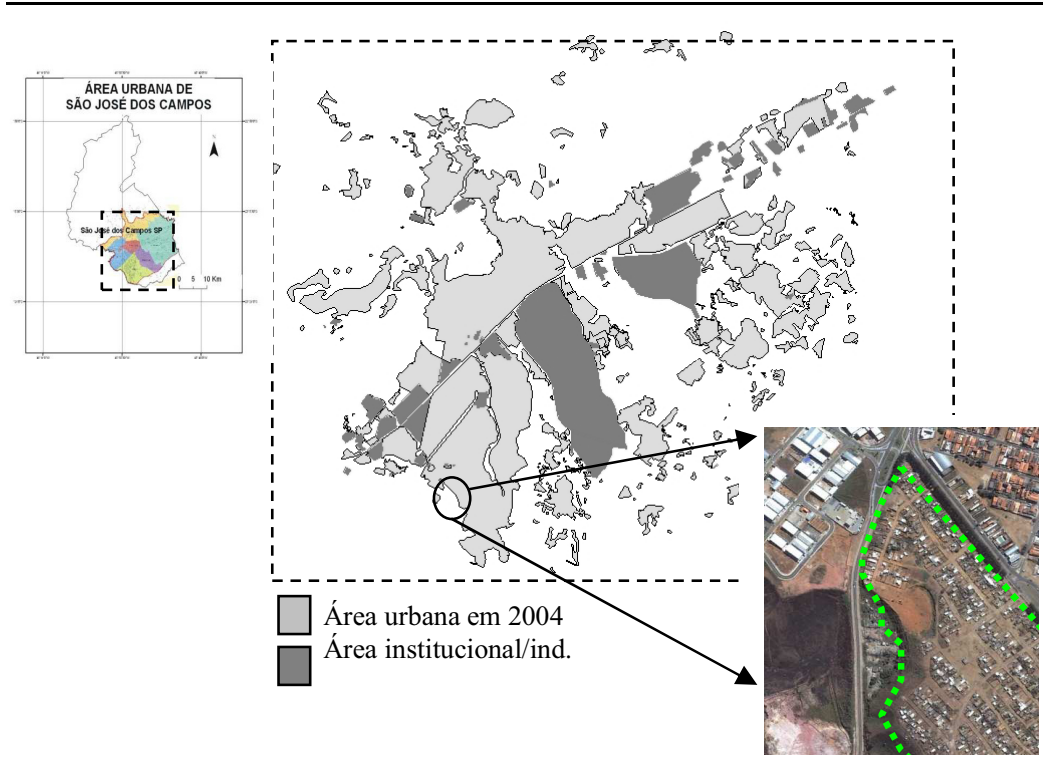

FIGURA 2: Área urbana do município de São José dos Campos e, em destaque, a ocupação Pinheirinho

Por tratar-se de uma ocupação, e não de uma favela, "cortiço" ou bairro "popular", há de se caracterizar algumas especificidades próprias deste "tipo" de espaço segregado. No final da década de 1970, segundo Rodrigues (2003), devido à crônica falta de alternativas do "onde" e do "como" morar, torna-se freqüente uma outra forma de solucionar esta questão: ocupar terra nas cidades. As ocupações demonstrariam uma luta pela sobrevivência, pela cidadania, uma capacidade de resistência, que desmistificaria o mito de apatia dos trabalhadores. As causas das ocupações são as mesmas da existência das favelas e, sua maior ocorrência nos últimos anos, decorre, além do déficit habitacional, ausência de uma política habitacional e dos espaços nas favelas encontrarem-se praticamente ocupados, é conseqüência de uma maior organização dos moradores da cidade. Diferentemente de 
FORLIN, L.G. \& COSTA, S.M.F. da. Urbanização e segregação sócio-...

uma favela, que se caracteriza por uma ocupação individual e cotidiana, ou seja, aqueles que não têm onde morar procuram um lugar para instalar-se com sua família, as ocupações ocorrem em bloco (figura 3), existindo um grupo de famílias que procuram em conjunto um área para instalar-se.

"As famílias que não podem pagar aluguel ou comprar casa/terreno, unem-se na busca de uma solução (...). Procuram o poder público e muitas vezes a ante-sala da repartição é o local onde se conhecem e onde começam uma organização. Pesquisam onde há áreas vazias, estabelecem uma data de ocupação conjunta e buscam a melhor maneira de resolver sua situação difícil de moradia (...). As ocupações caracterizam por uma mobilização anterior. As construções, embora de responsabilidade de cada família ocupante, são realizadas em verdadeiros "mutirões", em que as famílias que não contam com homens, são auxiliadas por outras" (RODRIGUES, 2003, p.43-45).

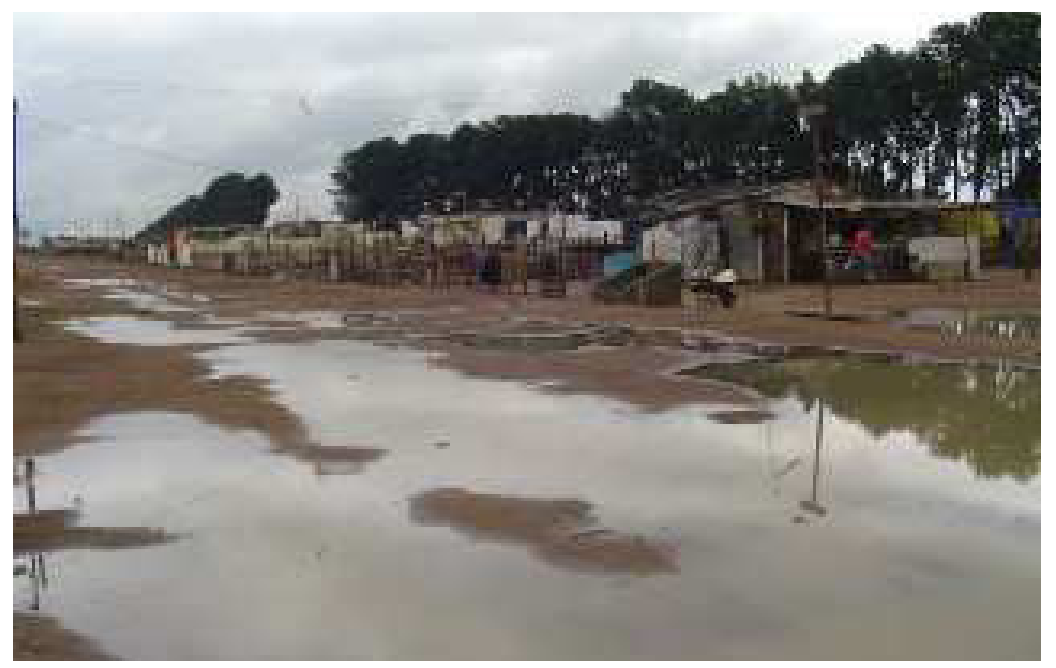

FIGURA 3: Fotografia panorâmica da ocupação Pinheirinho.

Fonte: Autores (2007) 
FORLIN, L.G. \& COSTA, S.M.F. da. Urbanização e segregação sócio-...

Assim, o planejamento da ocupação fica sob a responsabilidade dos moradores. Antes de entrar nas áreas escolhidas, eles definem a dimensão dos lotes, onde serão as ruas e mesmo possíveis áreas de comércio. No Pinheirinho, os lotes foram divididos, entre seus moradores, em 10 metros de largura e 25 metros de comprimento, cercados com madeira e arame. A água, usada para banho e na preparação de alimentos, é retirada de uma nascente próxima ao acampamento, sendo comum ver mulheres e crianças carregando baldes d'água pela "ocupação". A energia elétrica é obtida por ligações clandestinas na rede pública. Uma característica encontrada em outras ocupações, é que a maioria os barracos do Pinheirinho foi construído com pedaços de madeira e coberto com lonas plásticas. Entretanto, algumas moradias foram construídas com blocos de barro ou cimento (essa característica será mais bem detalhada no artigo) e cada barraco, normalmente de um cômodo, tem um banheiro no quintal. Vale lembrar aqui que a característica das moradias muda cotidianamente, com o passar do tempo. A substituição dos barracos de lona e madeira para os de bloco e cimento é uma tendência visível para qualquer transeunte que por ali passar.

À margem da legalidade, uma infra-estrutura foi montada. Além das conexões clandestinas de água e energia, um pequeno parque para as crianças foi construído e o comércio interno não só existe como possui vários estabelecimentos, desde bares, mercearias, salão de beleza, até hortas, bicicletaria, oficina de consertos em geral, etc. Ao todo, a ocupação possui em torno de 25 "pontos comerciais", como nossa pesquisa de campo nos revelou. Segundo relato de uma moradora que ganha a vida com uma mercearia no local, as vendas normalmente são unitárias, de produtos específicos. Segundo ela, era a primeira vez que "tocava um negócio seu" e que começou vendendo apenas pães. Mesmo relato foi descrito por uma moradora que montou um salão de beleza no local, com a mesma relatando que somente 12 anos após ter feito seu curso de cabeleireira, ela conseguiu montar seu salão. 
FORLIN, L.G. \& COSTA, S.M.F. da. Urbanização e segregação sócio-...

No local, um esquema de segurança realizado pelos sem-teto controla a entrada e permanência de pessoas que não moram no acampamento, que também conta com uma secretaria logo no portão principal de entrada. Nas assembléias que ocorrem semanalmente entre os moradores para discutir as ações do grupo, ocorreu a fundação do grupo Must (Movimento Urbano dos SemTeto), movimento este que é ligado ao Conlutas (Coordenação Nacional de Lutas), o qual foi criado em 2005, em Brasília (DF), e conta com a adesão de vários sindicatos da cidade.

A PMSJC já tentou por mais de dez vezes desocupar a área. Mandados de reintegração de posse foram efetivados por ela, sendo derrotados pelas diversas iniciativas políticas e jurídicas, tanto dos moradores da ocupação quanto dos sindicatos da cidade, em especial do Sindicato dos Metalúrgicos. Entre dezembro de 2004 e janeiro de 2005, por duas vezes foi marcado o despejo, mas uma combinação de atos de ruas, fechamento da rodovia Presidente Dutra e passeatas até a casa do atual prefeito da cidade, Eduardo Cury, e uma intensa atividade jurídica conseguiu suspender essas decisões.

A atitude da Prefeitura, desde a ocupação do Pinheirinho, tem sido de desqualificar e atacar o movimento dos sem-teto, chegando a oferecer passagens de volta para o local de origem para aqueles que não são de São José dos Campos, afirmando inúmeras vezes nos meios de comunicação que a maioria daquela população "é de fora de São José". No começo da ocupação, até mesmo multa estipulada em mil salários mínimos foi ventilada a ser aplicada pela Prefeitura caso casas de alvenaria e ruas fossem construídas no acampamento.

Segundo matéria do Jornal Vale Paraibano, do dia 6 de outubro de 2005, a Prefeitura também conseguiu uma liminar para cortar o fornecimento de água e energia elétrica para a população que vive no Pinheirinho, que mais uma vez só foi derrubada na última hora. A operação não foi colocada em prática porque os advogados do Sindicato dos Metalúrgicos e também do Must apresentaram ao juiz da $6^{\circ}$ Vara Cível uma medida cautelar, com pedido de liminar, para suspender o corte das ligações. Os 
FORLIN, L.G. \& COSTA, S.M.F. da. Urbanização e segregação sócio-...

advogados fundamentaram o pedido com o argumento de que está em tramitação na Bandeirante Energia (distribuidora de energia elétrica do Estado de São Paulo) um processo de regularização das ligações de energia elétrica dos sem-teto, além de já ter sido pedido à Telefônica (companhia de linhas telefônicas) a instalação de telefones públicos no local. A Prefeitura também vinha negando qualquer tipo de ajuda, como, por exemplo, a atuação da Defesa civil em casos de queda de barracos em época de chuvas. Segundo relatos dos moradores, a negação de atendimento em hospitais municipais é recorrente, bem como a matrícula em creches e escolas. A "senha" para o não atendimento ou matrícula é relatar que o endereço destes relaciona-se ao Pinheirinho.

Um fato importante, importante de ser ressaltado, em função dessa situação emergencial, foi a criação, em 2006, de uma comissão especial para acompanhar o caso por meio do Conselho de Defesa dos Direitos da Pessoa Humana (CDDPH), órgão ligado à Secretaria Especial dos Direitos Humanos, que visitou o acampamento a convite das lideranças do movimento de moradia para conhecer a realidade dessas famílias e reunir-se com representantes da Prefeitura para discutir o caso. Eles percorreram a ocupação, ouviram os relatos dos moradores, receberam denúncias, relatórios e outros materiais produzidos sobre a realidade dos sem-teto. Em entrevista à agência de notícias Carta Maior, no dia 10 de fevereiro de 2006, a Relatora Nacional do Direito à Moradia, Lúcia Maria Moraes, diz que "a situação do acampamento é crítica. Eles já moram na área há dois anos, ou seja, é uma ocupação consolidada, mas vivem em barracos de madeira", sem infraestrutura alguma, afirma a Relatora.

A comissão se reuniu com dois representantes da Prefeitura de São José dos Campos, o vice-prefeito, e o secretário de Assuntos Jurídicos (o Prefeito, de 2006 e atual - já que o mesmo foi reeleito - Eduardo Cury, negou-se a participar do encontro), que negaram que esteja ocorrendo um processo de exclusão dessa população. Eles afirmaram também que no momento não podem atender essas famílias nos programas habitacionais porque 
FORLIN, L.G. \& COSTA, S.M.F. da. Urbanização e segregação sócio-...

precisariam desestruturar a fila existente no município, com mais de 20 mil famílias cadastradas.

Na avaliação da secretária Nacional de Programas Urbanos do Ministério das Cidades, a urbanista Raquel Rolnik, em entrevista fornecida em 05/06/2006, à agência de notícias "Carta Maior" (SUCUPIRA, 2006), diz que existem dois elementos em comum entre todos os relatos e denúncias sobre os problemas habitacionais das cidades de São Paulo e São José dos Campos. Um deles é a resistência à idéia de que a população de baixa renda tem o direito a morar nas áreas centrais, consolidadas e boas dessas cidades. "Há a reiteração de um padrão de política habitacional que considera que o lugar de pobre é na periferia e não admite a hipótese de ter uma cidade mais coesa. Não podemos continuar a ter cidades partidas, segregadas, com guetos de pobres na periferia e áreas centrais desocupadas, subutilizadas. Mas existem obstáculos legais, administrativos, ideológicos e culturais para reverter isso", afirma a secretária. Outro ponto em comum, segundo ela, é o fato de que as gestões estaduais e municipais não admitem que a demanda habitacional possa ser negociada com o movimento popular organizado. "Para eles, tem que ser fila ou sorteio, métodos considerados mais transparentes e democráticos, mas que ignoram a história de organização e luta dos movimentos sociais e o papel que isso tem para o país. Negociar com eles significaria admitir que o movimento social é formulador e interlocutor da política pública e deve ser atendido pelo poder público", completa a urbanista, que confirmou a participação do Ministério das Cidades na comissão que estava sendo formada para enfrentar esses problemas.

Os sem-tetos do Pinheirinho exigem que a Prefeitura desaproprie o terreno, estabelecendo um conjunto habitacional no local. A intenção do movimento é que a legitimação de um bairro seja feita com uma infra-estrutura adequada aos moradores (atualmente, não há ruas com pavimentação pública no local). Importante frisar que a propriedade não recolhe Imposto Predial e Territorial Urbano há anos e já passou duas penhoras: uma em 1989 e outra em 1992, permanecendo penhorada até os dias de hoje 
FORLIN, L.G. \& COSTA, S.M.F. da. Urbanização e segregação sócio-...

em nome da Prefeitura Municipal, na Ação de Execução Fiscal 1403/92-SAF II. A Selecta faliu em 1991 e um de seus credores é a Prefeitura de São José dos Campos, conforme pode ser verificado no processo $\mathrm{n}^{\circ} 1023 / 89$, da $18^{\mathrm{a}}$ Vara Civil da Comarca da Capital.

A área não cumpre sua função social desde a década de 1970, quando foi adquirida, sendo que o déficit habitacional da cidade, como foi relatado, passa de 20 mil habitações. Segundo o Movimento, e informações veiculadas na mídia, os proprietários não pagam o IPTU do terreno desde 1983, quando passou a área foi incorporada ao perímetro urbano. A dívida com a Prefeitura de São José dos Campos já chegaria a R \$ 6 milhões de reais, o que corresponde ao valor venal da área. Independentemente disso, o Estatuto das Cidades fornece a base legal para que o terreno seja desapropriado para habitação popular. É nesta dívida que os advogados da ocupação se apóiam, afirmando que, se a Prefeitura quisesse, poderia aplicar a figura jurídica chamada "adjudicação", que consistiria a posse do terreno impetrada pela Prefeitura em troca da dívida, sem despender, diretamente, recursos financeiros. Como Maricato (2001) afirma, o governo municipal tem pouca influência na regulação do financiamento imobiliário mas tem muita importância na regulação fundiária e imobiliária urbana.

Outra ação envolveu não a desapropriação do terreno, mas a demolição dos barracos. Em dezembro 2005, a Prefeitura conseguiu uma liminar para que fossem demolidos os barracos do acampamento, a liminar foi concedida pela $1^{\text {a }}$ Vara da Fazenda Pública de São José e todo um destacamento da polícia Militar, Guarda Municipal, helicópteros, viaturas e reforços nos hospitais da região foram acionados. Somente próximo a data de demolição, o desembargador Aguilar Cortez, da $10^{\mathrm{a}}$ Câmara do Direito Público do Tribunal de Justiça de São Paulo, acionado pelos advogados da ocupação, concedeu, no mês de fevereiro de 2006, agravo de instrumento, cassando a liminar concedida à Prefeitura de São José, que determinava a derrubada das casas e barracos da ocupação Pinheirinho. Em Janeiro de 2010, o Governo do Estado de São Paulo colocou uma equipe técnica da CDHU (Companhia 
FORLIN, L.G. \& COSTA, S.M.F. da. Urbanização e segregação sócio-...

de Desenvolvimento Habitacional e Urbano) para analisar a área de ocupação do Pinheirinho para que seja realizado um estudo da viabilidade de compra do terreno pelo estado.

Com todos esses aspectos, o Pinheirinho embasa de forma elucidativa todos os processos amparados neste artigo, desde o reflexo do desenvolvimento do capital (que transforma uma cidade de perfil "interiorano" em um pólo técnico-industrial), da propriedade privada da terra, da terra colocada como "mercadoria", da especulação imobiliária, do conseqüente movimento segregacional, do pouco (ou nenhum) aporte de recursos a estas áreas (que podem ser consideradas áreas dos "não lugares"), do poder público, que escolhe para seus investimentos em bens e serviços coletivos os lugares onde estão os segmentos populacionais de maior poder aquisitivo. São fatores relacionais entre si e correlacionais com a ótica urbana do município de São José dos Campos. No próximo item, é apresentada uma análise mais detalhada de quem mora na ocupação do Pinheirinho, estabelecendo o perfilamento do mesmo.

\section{O perfilamento do segregado sócio-espacial urbano}

Este artigo buscou fazer uma aproximação do perfil do segregado espacial, mais especificamente do morador do Pinheirinho, lembrando que, dada as muitas similaridades existentes entre os espaços urbanos segregados, estabelecer o perfil do morador do Pinheirinho significaria conhecer, mesmo que existindo especificidades próprias para cada espaço segregado, o perfil daquele que vive na periferia urbana brasileira, morador da cidade de médio e grande porte. A pergunta recorrente que, norteou o início da pesquisa, era como caracterizar este perfil, como estabelecer um levantamento que possibilitasse, por exemplo, conhecer o tamanho das famílias, as médias das rendas salariais, as principais atividades dos que trabalham, as maiores carências percebidas pelo morador, as características das moradias construídas, as participações das famílias em programas sociais e 
FORLIN, L.G. \& COSTA, S.M.F. da. Urbanização e segregação sócio-...

entre outros inúmeros fatores, estudar a realidade de vida do morador do Pinheirinho, deste segregado espacial.

$\mathrm{O}$ instrumento usado para o levantamento desta realidade foi a aplicação de questionários na ocupação. Dentre os critérios utilizados, chegou-se ao consenso de que, para levantarmos um perfil verossímil, próximo à realidade, no mínimo $10 \%$ das famílias teriam de ser entrevistadas. Segundo os dados da própria ocupação e, levando-se em conta estes, já que os números da Prefeitura de São José dos Campos são inferiores, o terreno do Pinheirinho, de mais de 1 milhão de metros quadrados, abriga cerca de 7.000 pessoas e 1.500 famílias. Assim, o questionário, como foi destinado a ser aplicado nos domicílios, para as famílias, foi aplicado em 150 domicílios, ou seja, a $10 \%$ das famílias. No questionário, 10 questões foram "fechadas", com alternativas específicas de respostas, e três questões foram "abertas", cabendo ao entrevistado estabelecer qualquer tipo de resposta. Os questionários foram aplicados no período de junho a outubro de 2006.

Muitos questionários foram aplicados nos encontros semanais realizados pela ocupação que, geralmente, tem grande participação dos moradores, seja dos jovens, dos adultos ou idosos, lembrando que os mesmos, respondiam as questões como que representando a família. Outro ponto é que, mesmo a ocupação sendo de grande extensão, quando o questionário foi aplicado diretamente na moradia de cada família, a pesquisa teve a preocupação de não concentrar as aplicações do questionário somente num determinado espaço do Pinheirinho. Assim, todas as ruas foram cobertas de forma a captar a diversidade existente, considerando que o mesmo, como fruto das próprias ramificações capitalistas, também apresenta suas diferenciações. São as desigualdades no interior do diferente, particular e desigual.

\section{Realidade e cotidiano do morador do Pinheirinho}

Uma das questões do questionário voltou-se a elucidar o movimento migratório que as famílias fizeram antes de estabelecer 
FORLIN, L.G. \& COSTA, S.M.F. da. Urbanização e segregação sócio-...

moradia no Pinheirinho (Figura 4). Das 150 famílias entrevistadas, apenas 12 , ou $8 \%$ disseram ter vindo de outras regiões do país (cidades dos Estados do Paraná, de Minas Gerais e do Nordeste foram citados), 18 famílias ou 12\% delas vieram de outras cidades do Estado de São Paulo (Jacareí, Taubaté, Caçapava e cidades do litoral norte foram citadas) e, 120 famílias, ou $80 \%$ das respostas, afirmaram ter vindo de outros bairros da cidade de São José dos Campos. Um dado interessante é que, destes $80 \%$, 90 famílias, ou $60 \%$ delas, declararam ter vindo da Zona Sul da cidade (reconhecidamente, uma das áreas mais empobrecidas do município, onde se localiza a ocupação), de bairros adjacentes ao Pinheirinho, principalmente do bairro Campo dos Alemães. Estes dados nos mostram o quanto é carente a cidade de melhores políticas habitacionais, descaracterizando também o discurso da Prefeitura de São José dos Campos, segundo a qual as ocupações da cidade têm origem em outras cidades e que os moradores do Pinheirinho são, em sua maioria, migrantes de outras regiões (como noticiado em veículos de comunicação).

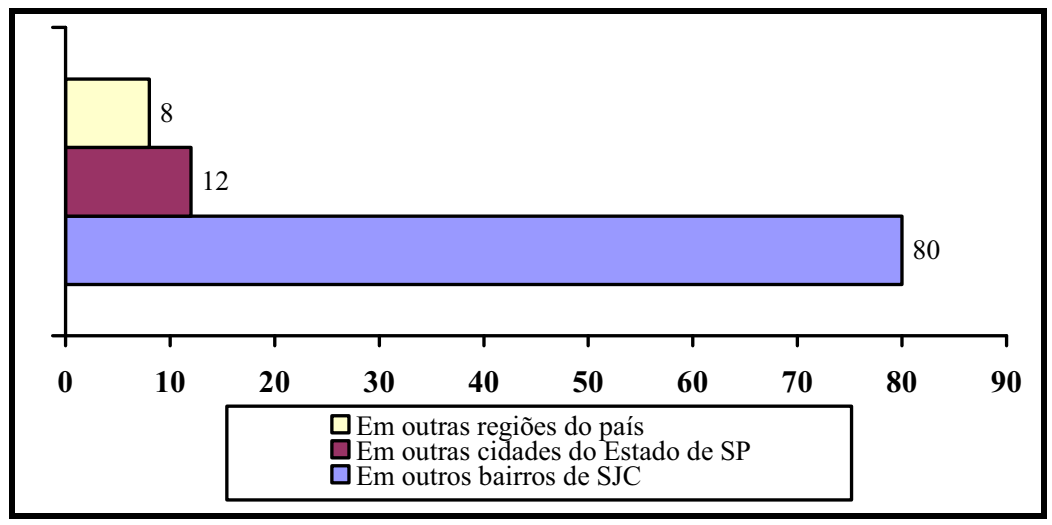

FIGURA 4: Local de Moradia anterior ao Pinheirinho (\%)

Quanto à renda familiar, os dados refletiram a condição de segregados deste segmento populacional. Mais da metade das 
FORLIN, L.G. \& COSTA, S.M.F. da. Urbanização e segregação sócio-...

famílias do Pinheirinho, ou $60 \%$ das moradias, vivem com menos de um salário mínimo, (menos de $\mathrm{R} \$ 350,00$ reais mensais, na época da entrevista). É considerável também o número de famílias que sobrevivem com menos de $\mathrm{R} \$ 100,00$ reais mensais: $16 \%$ das famílias entrevistadas. Essas famílias não possuem recursos suficientes para se alimentar (aqui, a maioria tem como atividade única a reciclagem, sendo esta a única forma de renda da família, como será visto adiante). Muitas famílias vivem com renda entre $\mathrm{R} \$ 100,00$ e $\mathrm{R} \$ 350,00$, representando $44 \%$ das respostas. As famílias que possuem renda familiar entre $\mathrm{R} \$ 350,00$ e $\mathrm{R} \$ 500.00$ reais mensais representam $32 \%$ das respostas e entre $R \$ 500,00$ e $\mathrm{R} \$ 700,00$ reais, $8 \%$ dos entrevistados.

Outro dado levantado nesta questão do trabalho refere-se à quantidade de trabalhadores que estão exercendo alguma atividade, seja no mercado formal, com carteira assinada, seja no mercado informal, sem carteira assinada, lembrando que no questionário perguntava-se se havia alguém na família que possuía carteira assinada. Os números, mais uma vez, expressam a realidade brasileira: $76 \%$ das famílias declararam que não possuíam ninguém em suas moradias que possuísse carteira assinada e apenas $24 \%$ declararam que havia algum membro familiar com carteira registrada formalmente.

Estes dados são o reflexo dos tipos de atividades dos trabalhadores do Pinheirinho (figura 5), que exercem uma mescla de várias formas de trabalhos informais. Entre os principais tipos de atividades geradoras de renda, a reciclagem de lixo obteve a maior parte das citações, com $36 \%$ das respostas, quase o dobro das citações dadas a segunda maior atividade. O serviço de catadores, principalmente dos catadores de papel e de alumínio, mostra-se de fundamental importância dentro da economia dos núcleos familiares do Pinheirinho, e é desempenhado, sem distinção, pelo pai, pela mãe ou pelos filhos.

Quando se diziam catadores, as respostas se dividiam entre os conceitos de "estar" e de "ser" catador, sentiam-se percebidos pela população ora como estorvo, como marginais, mas também 
FORLIN, L.G. \& COSTA, S.M.F. da. Urbanização e segregação sócio-...

identificavam algumas vantagens em ser catadores, como por exemplo, os rendimentos, a maior autonomia na definição da organização do trabalho e a ausência da figura do "chefe". Verificamos que há diferentes visões sobre o "estar" catador, como por exemplo, os "profissionais", os que têm a "visão empresarial" e realizam a atividade mais sistematicamente e os que têm a atividade como biscate, estando a família, ou o morador, exercendo a atividade simplesmente por que não há outra opção.

巴Faxineira/Babá

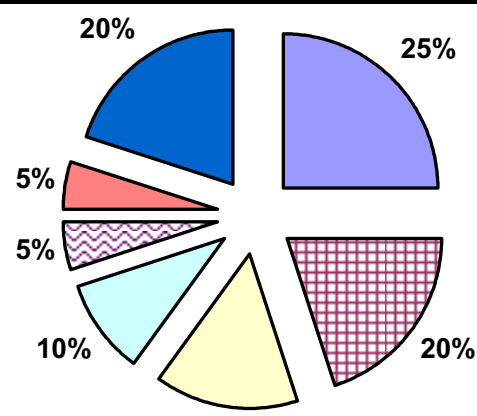

$15 \%$

$\square$ Serviços gerais (pintor/carpinteiro/pedreiro)

$\square$ Frentes de trabalho

๑Aposentadoria/Pensão

$\square$ Bolsa-Família/ Bolsa-Escola

$\square$ Outras atividades citadas (garçom, balconista, empacotador, frentista, etc.)

FIGURA 5: Principais atividades geradoras de renda

A segunda atividade mais citada foi a de ambulantes, de pessoas que trabalham com algum tipo de venda na rua, ou em casa, tendo sido citado por $20 \%$ dos entrevistados. Toda família que trabalha com algum tipo de venda, foi alinhada nesta linha de atividade. Outra atividade bem citada é o serviço de babá/faxineira, com $16 \%$ das respostas. O interessante nesta resposta é que a maioria das mulheres que declaravam exercer este tipo de serviço relatava que, para conseguir o emprego, seja ele de caráter 
FORLIN, L.G. \& COSTA, S.M.F. da. Urbanização e segregação sócio-...

temporário ou fixo, elas diziam para as contratantes de seus serviços que moravam em outros bairros, geralmente dando endereços de parentes, pois muitas não conseguiam emprego ao dizer onde residiam verdadeiramente.

Serviços gerais, estes desempenhados pelos homens, como atividades de pintor, de carpinteiro e de pedreiro, aqueles que trabalham de alguma forma com o leque "consertos em geral", resolvendo eventuais problemas que ocorrem em qualquer moradia e apreendidos conforme a experiência de vida, de forma quase auto-didata, foram a terceira atividade mais citada, com $12 \%$ das respostas. Foi comum, ao citar este tipo de trabalho, a família reclamar do tempo ocioso que o pai ou marido tinha, já que normalmente esse tipo de emprego era conseguido de forma esporádica, com tempo de atividade indefinida, sendo este rol de "serviços gerais" mais caracterizados como "bicos gerais".

Outras atividades geradoras de renda que tiveram poucas citações (sendo citadas muitas vezes uma única vez), sem uma fatia expressiva das citações, foram englobadas conjuntamente, somando $16 \%$ das respostas. São várias as atividades citadas e, aqui, muitas destas atividades têm a característica de ser emprego formal, com carteira assinada, por isso serem citadas escassamente. Os exemplos das atividades são inúmeros: garçom, frentista, empacotador de supermercado, cabeleireira, balconista/vendedor, etc.

Outra fonte de renda citada, que não caracteriza uma atividade, mas configura um dado extremamente importante a ser analisado, são as rendas atribuídas aos programas sociais do Governo Federal, mais especificamente o "Bolsa Família". Apenas $4 \%$ das famílias declararam ter o benefício e todas estas

${ }^{5}$ Este programa, o Bolsa Família, unificou todos os benefícios sociais (Bolsa Escola, Bolsa Alimentação, Cartão Alimentação e Auxílio Gás) do Governo Federal num único programa de transferência de renda destinado às famílias em situação de pobreza, com renda per capita de até R \$100,00 mensais, que, teoricamente, associa à transferência do benefício financeiro o acesso aos direitos sociais básicos: saúde, alimentação, educação e assistência social. 
FORLIN, L.G. \& COSTA, S.M.F. da. Urbanização e segregação sócio-...

famílias afirmaram ser este benefício a principal fonte de renda da família, o que denota a importância deste programa para os seus sustentos. Para ter o benefício do "Bolsa Família", é necessário a família estar numa situação de pobreza, esta confirmada quando a família tem uma renda mensal inferior a $\mathrm{R} \$ 100,00$ reais por pessoa, caracterizando assim seu direito ao recebimento do benefício da bolsa. Assim, causa surpresa quando verificamos que apenas $4 \%$ dos entrevistados citaram este Programa Social como fonte de renda, sendo que $80 \%$ das famílias do Pinheirinho, segundo os dados do questionário, estão nesta situação, ou seja, as famílias, majoritariamente, têm renda abaixo do que é caracterizado como requisito para o recebimento da Bolsa Família. A maioria dos $20 \%$ dos entrevistados que declararam renda acima de $\mathrm{R} \$ 100,00$ reais $(16 \%)$ consistia em casas onde moravam apenas duas pessoas, normalmente casais que possuíam renda em torno de um salário mínimo (embora casais com renda inferior a $\mathrm{R} \$ 100,00$ também foram encontrados). Quando o número de componentes da família passava de 2, a família entraria no bloco das famílias que vivem com menos de $\mathrm{R} \$ 100,00$ reais por pessoa.

Outro questionamento foi se a família ou morador participava dos programas sociais do município (ou federais). A pergunta aqui se refere não só a programas de transferência de renda, como o "Bolsa Família", citado anteriormente, mas sim, a qualquer tipo de ajuda ou benefício recebido pela família. Os resultados revelam, mais uma vez, a situação de exclusão que esta população vive em seu dia-a-dia. Do total, $52 \%$ das famílias não recebem nenhum tipo de ajuda ou benefício e $48 \%$ responderam que sim, que recebem algum tipo de ajuda. Destes $48 \%$ que responderam que recebem benefícios, $44 \%$ recebem somente cestas básicas e os outros $4 \%$ recebem ajuda do programa federal, o Bolsa Família, como relatado anteriormente. Um fato a ressaltar é que esta distribuição de cestas básicas, segundo relatos da maioria dos moradores, não ocorre de forma sistemática, mensalmente. Os moradores, usualmente, não estão inseridos em programas de distribuição destas cestas. Elas são adquiridas quando os mesmos 
FORLIN, L.G. \& COSTA, S.M.F. da. Urbanização e segregação sócio-...

as solicitam a órgãos ou instituições de ajuda humanitária (como a igreja) e, muitas vezes, quando os moradores têm de fazer qualquer cadastro pra receber o auxílio, os endereços verdadeiros, do Pinheirinho, na maioria das vezes não são passados, e sim os endereços de parentes ou amigos de outros bairros.

A pergunta que fica é por quê a população do Pinheirinho não é atendida pelo programa Bolsa Família de forma realmente efetiva? Por quê mesmo assistências simples, obrigatórias, destinadas a estas camadas da sociedade, como entrega de cestas básicas, quando não são negadas (vide a "lei da fome" estruturada e aprovada pelos membros da atual gestão do poder público joseense, como descrito anteriormente), são entregues de forma precária, rarefeita, esporádica? Neste viés, o professor Milton Santos afirma:

"O simples nascer investe o indivíduo de uma soma inalienável de direitos, apenas pelo fato de ingressar na sociedade humana. Viver, tornar-se um ser no mundo, é assumir, com os demais, uma herança moral, que faz de cada um portador de prerrogativas sociais. Direito a um teto, à comida, à educação, à saúde, à proteção contra o frio, à chuva, as intempéries; direito ao trabalho, à justiça, à liberdade e a uma existência digna (...), o discurso das liberdades humanas e dos direitos seus garantidores é, certamente, ainda mais vasto. Tantas vezes proclamado e repetido, tantas vezes menosprezado. É isso, justamente, o que faz a diferença entre a retórica e o fato. $\mathrm{O}$ respeito ao indivíduo é a consagração da cidadania (...) ameaçada por um cotidiano implacável, não basta à cidadania ser um estado de espírito ou uma declaração de intenções (...). A cidadania pode começar por definições abstratas, cabíveis em qualquer tempo e lugar, mas para ser válida deve poder ser reclamada" (SANTOS, 1993, p.7-8).

Outro dado relevante averiguado, dado o objetivo deste artigo em estabelecer correlações entre a segregação e a questão 
FORLIN, L.G. \& COSTA, S.M.F. da. Urbanização e segregação sócio-...

habitacional, é a participação da família ou morador do Pinheirinho em programas habitacionais do município.

Foram 90 citações, ou $60 \%$ as respostas, que declararam nunca ter participado de programas habitacionais, sendo aqui reconhecida a situação do não direito à cidadania desta população. $\mathrm{O}$ mesmo processo que os impedem de participar de benefícios sociais, também os impede de ter acesso aos programas habitacionais.

O absurdo também se faz presente ao analisarmos aqueles que estão ou estiveram na lista de espera por uma casa em algum programa habitacional. Apesar das condições adversas enfrentadas ao longo da vida pela maioria das famílias, apenas $40 \%$ delas disseram ter participado de qualquer programa deste tipo e destes $40 \%$ que já participaram, 24\% estão há mais de 5 anos na lista de espera por uma casa e $12 \%$ estão há mais de 10 anos. Diante destes fatos, como ainda podem ocorrer questionamentos em torno da legitimidade das ocupações, dos "por quês" que resultam na configuração de loteamentos clandestinos, favelas e cortiços?

Números sobre a escolaridade dos chefes de família constituem outra análise levantada nas entrevistas e aqui, mais uma vez, os dados mostram o perfil do segregado social-urbano brasileiro. $\mathrm{Na}$ análise dos dados, vê-se que os analfabetos moradores do Pinheirinho ultrapassam a média de analfabetos do Brasil. Enquanto o país possui, segundo o IBGE (2006), 12,4\% da população sem estudo (entre a população com 15 anos ou mais), o Pinheirinho, segundo o levantamento realizado, apresenta uma taxa elevada, de 16\% dos chefes de família.

Outra preocupação da pesquisa refere-se aos maiores anseios das famílias, àquilo que eles mais sentem falta na ocupação. $\mathrm{O}$ resultado pode ser conferido na figura 6 .

Como pode ser observado, as respostas referentes à conquista da regularização da área mostrou amplo domínio sobre as demais citações, obtendo $60 \%$ das respostas. Para esse questionamento, era comum o morador responder que seu maior sonho era sentir-se verdadeiramente dono de sua casa, de seu 
FORLIN, L.G. \& COSTA, S.M.F. da. Urbanização e segregação sócio-...

"pedaço de chão" sem medo do que o futuro reservaria a ele bem como "sentir-se morador de um bairro de verdade".

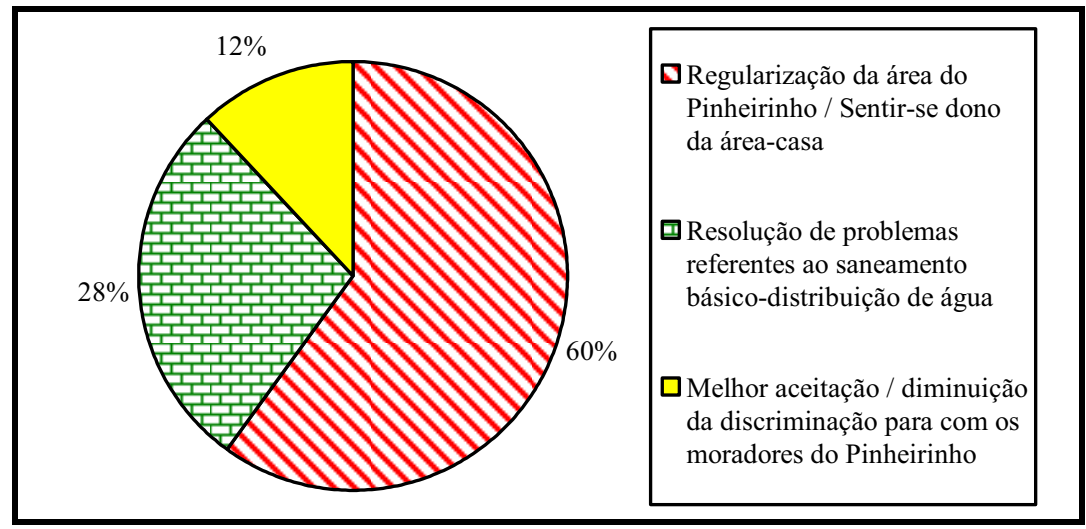

FIGURA 6: Maior carência sentida pela família/morador

As análises em torno do perfil do morador do Pinheirinho ainda encontrariam outras correlações, que podem e devem ser melhor analisadas em futuros estudos. $\mathrm{O}$ artigo teve a preocupação de amparar "frentes" imprescindíveis para o entendimento da condição de exclusão destes moradores, comparando, por exemplo, o perfil de suas moradias e de seus modelos de trabalho, sua origem, caracterizando a mobilidade espacial dos mesmos antes de estabelecer moradia no Pinheirinho, a relação destes com os programas sociais municipais e federais, entre outras questões. $\mathrm{O}$ perfilamento apresentado é uma amostra das condições real de vida do morador do Pinheirinho, como reflexo sistêmico da condição segregadora da realidade intra-urbana brasileira.

\section{Considerações finais}

Como discutido, a disparidade sócio-espacial e o movimento segregacional, tão comum ao se falar de Brasil, principalmente dentro de seu modelo de urbanização ao longo das últimas quatro 
FORLIN, L.G. \& COSTA, S.M.F. da. Urbanização e segregação sócio-...

décadas, encontra reflexo, perceptivelmente, na cidade de São José dos Campos, sendo a ocupação do Pinheirinho, exemplar evidente deste processo. Dentro do Estado de São Paulo, poucas cidades têm movimento de segregação e periferização de determinados segmentos populacionais tão evidentes, como São José dos Campos. A análise do Pinheirinho demonstra e é confirmado pelo relato do que foi observado por uma comitiva do Conselho de Defesa dos Direitos da Pessoa Humana (CDDPH), órgão ligado à Secretaria Especial dos Direitos Humanos, ao averiguar o sistemático processo de exclusão social da cidade (única, aliás, a receber tal comitiva fora do eixo da capital paulista).

A reestruturação produtiva do capitalismo internacional, do final do século XX, que tem sido chamada de globalização, tem relações com a evolução da exclusão sócio-espacial aqui relatada. A via tecnológica interfere não só no modelo de produção, mas a empregabilidade do trabalhador, a informatização crescente, a imposição e rapidez da via comunicacional conjugou ao capitalismo condições de mudar a relação espaço e tempo, que são outros e estão em permanente mutação. Como Maricato (2001) avalia, apesar da roupagem democrática e participativa, as propostas dos "planos estratégicos", vendidos às subeconomias dos países subdesenvolvidos, se combinaram ao ideário neoliberal. Isso alinhou economias, como a brasileira, ao estruturado "Consenso de Washington", subordinando governos às novas exigências do processo de acumulação capitalista. $\mathrm{O}$ "plano estratégico" adquiria discurso vazio pelo plano modernista, num cenário caracterizado pela desregulamentação e crise fiscal e um urbanismo burocrático que não levou em conta as potencialidades e as redes comunitárias e sociais locais, isso tudo somado ainda ao atrelamento políticoeconômico dimensionado pela dívida externa. Assim, comumente, não há política social no rol primeiro de qualquer meta governamental. Para Maricato (2001), a democratização da produção de novas moradias e do acesso à moradia legal e à cidade com seus serviços e infra-estrutura exigiria a modulação de duas vias: terra urbanizada e financiamento que, durante toda a história 
FORLIN, L.G. \& COSTA, S.M.F. da. Urbanização e segregação sócio-...

da urbanização brasileira, foram vias proibidas para a maior parte da população. Mais do que um direito à cidade, o que o artigo procurou evidenciar é o direito a obter da sociedade aqueles bens mínimos, sem os quais a existência torna-se indigna.

Como o professor Milton Santos avalia, em algum momento a idéia de uma sociedade civil imbuída, consciente, com vocação para a igualdade foi deixada ao largo para evocação de um espírito astuto, maquinário e industrial, a ditar não só relações de mercado mas também aos intercâmbios sociais, corroborando o consumo em si mesmo e suprimindo uma vida comunitária baseada em solidariedade social (SANTOS, 1993). O que reina é a simbologia da propaganda, a cultura de massas, deixando estas não mais fruto das particularidades, do único que diferenciava mais unia, mas sim mais um item a ser fabricado, servindo de ponte à ideologias imperceptíveis e à alienação.

A exclusão, primeiramente social e, posteriormente sócioespacial (com o capitalismo adquirindo novas ramificações) é ponto comum (pelo menos deveria ser) em qualquer análise proposta a ser feita sobre o Brasil, em qualquer esfera científica.

Dentro destas considerações, seria imprescindível trazer à discussão fatos recentes que evidenciam e elevam o conceito de "direito à cidade", os quais estão sendo travados com medidas próPinheirinho, dentro da esfera do conflito entre o poder público municipal e mesmo em escala federal. A importância da discussão em torno das questões que envolvem o Pinheirinho (desapropriação da área, demolição dos barracos, convocação de aparato policial para instituir "segurança" e retirar as famílias, não disponibilidade de benefícios sociais, etc.) é tão evidente, principalmente no que diz respeito à solução do caso. O Ministério das Cidades confirmou que está disposto a financiar, por meio de programas habitacionais patrocinados pela Caixa Econômica Federal, cerca de 90\% dos custos para urbanização e construção de moradias na área do Pinheirinho. De acordo com o gerente de Regularização Fundiária do Ministério, Sérgio Andrea, o plano já teria sido levado ao conhecimento da secretária de Habitação, Maria Rita Singulano, no 
FORLIN, L.G. \& COSTA, S.M.F. da. Urbanização e segregação sócio-...

ano 2005, em uma reunião em Brasília. O fim do impasse é a meta do Ministério das Cidades. Em contrapartida, a secretária de Governo, Claude Mary de Moura, já afirmou diversas vezes, que o prefeito Eduardo Cury não tem intenção de desapropriar a área e que a proposta do Ministério das Cidades não foi formalizada.

Mais recentemente, no início de 2010, o governo federal anunciou que quer utilizar recursos do FGTS (Fundo de Garantia por Tempo de Serviço) para financiar vendas de lotes para as mais de 1500 famílias sem-teto da ocupação. A proposta foi discutida em uma reunião no Ministério das Cidades, com a participação dos semteto e representantes da massa falida da empresa Selecta, proprietária da área. A intervenção do governo federal na crise do Pinheirinho foi solicitada pelo senador Eduardo Suplicy e contraria a administração do município, que se recusa a negociar com os sem-teto. A intenção dos sem-teto e de seus advogados é utilizar a resolução 460, da Caixa Econômica Federal, que prevê o financiamento de moradia para as pessoas de baixa renda. A negociação também foi conduzida pelo gerente de projetos e mediador de conflitos urbanos do Ministério das Cidades, Sérgio Andrea e, segundo ele, o Ministério entraria na negociação como um normatizador. $\mathrm{O}$ maior entrave na negociação é a Prefeitura que, por diversas vezes, entrou com ação para demolição dos barracos do Pinheirinho.

Como se observa, o conflito ainda dispenderá inúmeros movimentos e a oficialização/desapropriação da área ainda poderá ser postergada por tempo indefinido (isto se tal desapropriação for efetivada). Mesmo existindo alternativas para solucionar o problema na escalas do poder público municipal, que vão ao encontro dos anseios da população do Pinheirinho (como a ação do Ministério das Cidades), as ações que vão neste sentido são raras. As dificuldades em legitimar a ocupação ainda são muito grandes pois uma eventual vitória de um movimento social-urbano, como os do sem-tetos, ante o poder público significaria romper uma estrutura bem montada que defende os interesses de uma minoria que se mantém no poder e confunde-se com o mercado imobiliário da cidade, beneficiando-se de "vazios" urbanos como o do Pinheirinho $\mathrm{O}$ quanto este 
FORLIN, L.G. \& COSTA, S.M.F. da. Urbanização e segregação sócio-...

"mercado", não perderia com a efetivação de um bairro extremamente popular como o Pinheirinho? É uma via que merece ser analisada em outras pesquisas, sem dúvida.

Acreditamos numa cidade melhor, com mais equidade social e, para isso, precisamos conhecer melhor o espaço que nos cerca, sem propostas pré-fabricadas e pré-conceituosas. Só o conhecimento acerca da realidade desta amostra excludente de cidade poderá desencadear ações positivas que visem sanar o quadro que estrutura estas "dívidas" sociais urbanas. Desta forma, pode-se contribuir, mesmo que minimamente, para uma equação destes problemas no que tange ao planejamento urbano e ao estabelecimento de melhores políticas públicas no município, principalmente no que se refere às políticas públicas habitacionais em São José dos Campos.

\section{Agradecimentos}

Os autores agradecem À FAPESP (Fundação de Amparo à Pesquisa do Estado de São Paulo) pelo apoio financeiro recebido ao longo do desenvolvimento desta pesquisa, na forma de bolsa e auxílio à pesquisa, sem o qual a mesma se tornaria inviável.

\section{Referências bibliográficas}

FREITAS, Rosângela Nicolay. Avaliação dos vazios existentes na macrozona urbana de São José dos Campos. Dissertação (Mestrado em Planejamento Urbano e Regional). Instituto de Pesquisa e Desenvolvimento. São José dos Campos: UNIVAP, 2004.

GOLVÊA, Rosana A. R. O espaço urbano e a clandestinidade. Dissertação. (Mestrado em Planejamento Urbano e Regional). Instituto de Pesquisa e Desenvolvimento. São José dos Campos: UNIVAP, 2003. 
FORLIN, L.G. \& COSTA, S.M.F. da. Urbanização e segregação sócio-...

IBGE (Brasil). Instituto Brasileiro de Geografia e Estatísticas. IBGE - Trabalho e Renda. Disponível em: $<$ http://www.ibge.gov.br/home/estatistica/populacao/trabalhoerend imento/pnad2005/brasil/tabr4_28.pdf >. Acesso em: 04 mar. 2010.

MARICATO, Ermínia. Brasil, cidades - alternativas para a crise urbana. Rio de Janeiro: Vozes, 2001.

PMSJC Prefeitura Municipal de São José dos Campos; NEPO Núcleo de Estudos Populacionais da UNICAMP. Pesquisa de Instrumentação do Planejamento Urbano e Avaliação do Déficit Habitacional em São José dos Campos. São José dos Campos: PMSJC, 2003.

ROLNICK, Raquel. A cidade e a lei. São Paulo: HUCITEC, 2006.

RODRIGUES, Arlete Moysés. Moradia nas Cidades Brasileiras. São Paulo: Contexto,2003.

SANTOS, Milton. O espaço do cidadão. São Paulo: Nobel, 1993.

SOUZA, Iris de Marcelhas. Análise do Espaço Intra-Urbano para Estimativa Populacional Intercensitária Utilizando Dados Orbitais de Alta Resolução Espacial. 2003. Dissertação (Mestrado em Planejamento Urbano e Regional). Instituto de Pesquisa e Planejamento. São José dos Campos: Univap.

SUCUPIRA, Fernanda. Comissão investiga violação do direito à moradia em SP. Disponível em http://www.cartamaior.com.br/ templates/materiaImprimir.cfm?materia_ id $=1137$, de 05/06/2006. Acesso em: outubro de 2006.

Recebido em novembro de 2008 Aceito em maio de 2010 